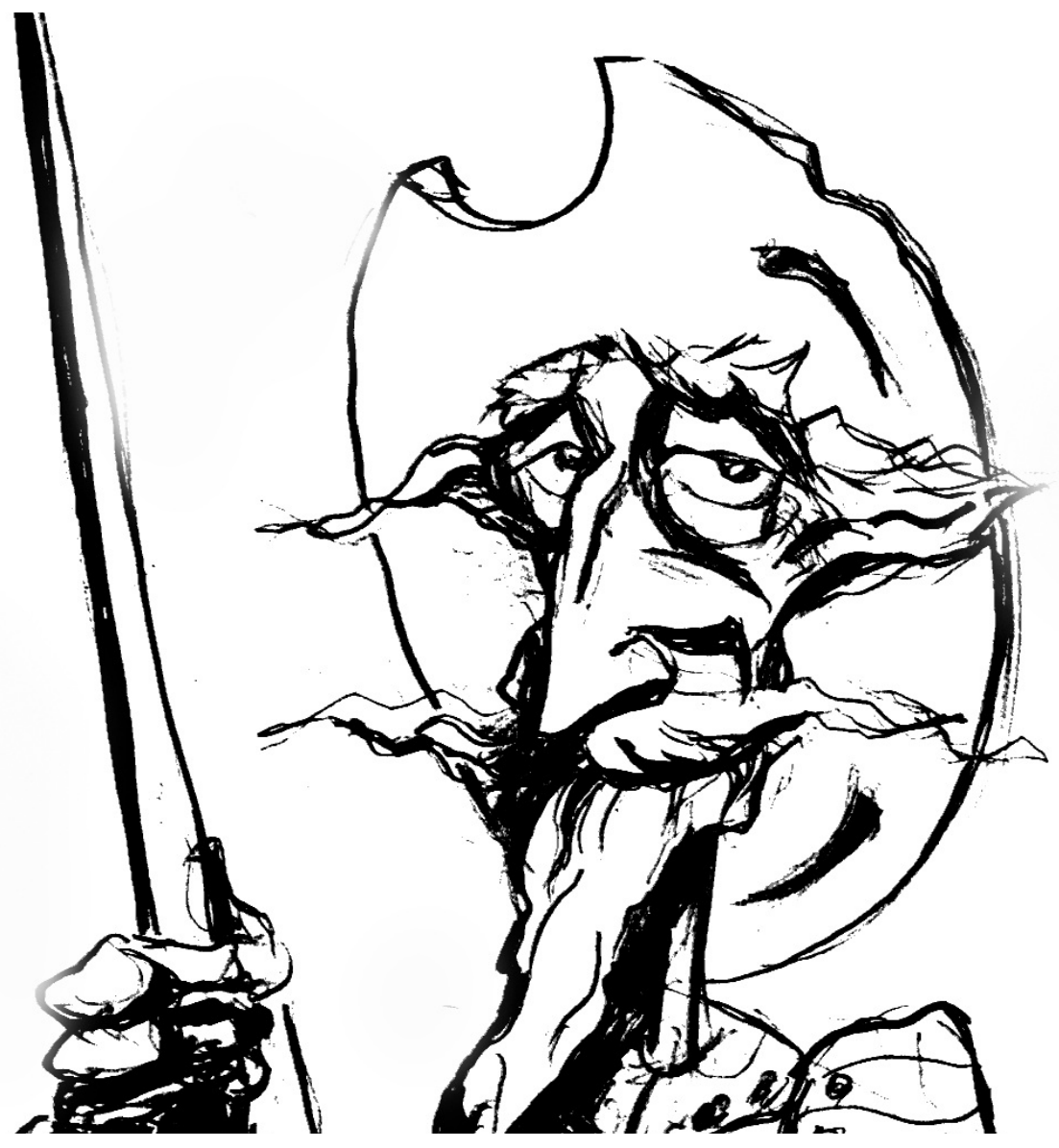

"Dios y el Rey son contentos que los siervos lleguen a su libertad". Esclavos y Defensores de pobres en el Buenos Aires tardocolonial

[Lucas Rebagliati] 



\title{
"Dios y el Rey son contentos que los siervos lleguen a su libertad". Esclavos y Defensores de pobres en el Buenos Aires tardocolonial
}

\author{
"Dios y el Rey son contentos que los siervos lleguen a su libertad". Slaves and \\ Defensores de Pobres in Late Colonial Buenos Aires
}

LUCAS REBAGLIATI

\begin{abstract}
Resumen
La historiografía hispanoamericanista ha explorado en forma sistemática como los esclavos y esclavas durante la época colonial recurrieron a las justicias en pos de mitigar los abusos que sufrían por parte de sus amos. El presente artículo se propone indagar-mediante el análisis de un corpus documental compuesto de 41 procesos judiciales- una cuestión escasamente atendida en el marco de esta problemática mayor. La naturaleza del patrocinio jurídico que recibían estos africanos/as y afrodescendientes en Buenos Aires por parte de un peculiar agente de justicia destinado a tal fin. El "regidor defensor general de pobres" del ayuntamiento, quien desempeñó esta función en forma regular entre 1776 y 1810.
\end{abstract}

Palabras clave

Esclavos; defensores de pobres; justicia; Buenos Aires; época tardocolonial

\begin{abstract}
Hispanic American historiography has systematically explored how slaves during colonial times resorted to the justices in order to mitigate the abuses that suffered from their masters. The present article proposes to investigate -through the analysis of 41 judicial records- a barely addressed issue within the framework of this major problem. The nature of the legal sponsorship that enslaved Africans and Afrodescendants received in Buenos Aires by a special Justice Officer: the "regidor defensor general de pobres" of the city council, who carried out this function on a regular basis between 1776 and 1810 .
\end{abstract}

\section{Key Words}

Slaves; defensores de pobres; justice; Buenos Aires; late colonial period

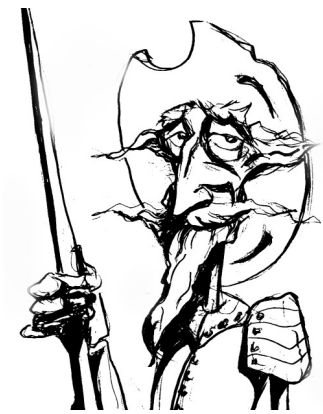

Recibido con pedido de publicación el 15 de mayo de 2019 Aceptado para su publicación el 20 de julio de 2019

Versión definitiva recibida el 15 de octubre de 2019

Lucas Esteban Rebagliati, Universidad de Buenos Aires, Consejo Nacional de Investigaciones Científicas y Técnicas, Buenos Aires, Universidad Nacional de Avellaneda, Avellaneda, Argentina; email: lucasrebagliati@hotmail.com

Esta obra se publica bajo licencia Creative Commons. Atribución-NoComercial-CompartirIgual $($ (c) EY-NC-SA 4.0 Internacional

Rebagliati, Lucas “'Dios y el Rey son contentos que los siervos lleguen a su libertad'. Esclavos y Defensores de pobres en el Buenos Aires tardocolonial", Prohistoria, Año XXII, núm. 32, dic. 2019, pp. 35-67 


\section{Introducción ${ }^{1}$}

El seis de noviembre de 1772, en la ciudad de Buenos Aires el esclavo mulato Joseph Atanasio -de diecisiete años- fue vendido a Antonio Vélez, por el precio de 225 pesos. En el documento donde fue registrada la venta, se aclaraba que en caso de querer venderlo, el nuevo dueño debía hacerlo por el mismo valor por el cual lo había adquirido. Cinco años después, cuando Atanasio cumplió 22 años, su padre se ofreció a pagar por su libertad, pero Vélez determinó un precio superior al acordado en su momento. Ello motivó que Atanasio -en un rudimentario escrito sin firma- solicitara justicia directamente al Virrey. Pedro Cevallos decidió no resolver la cuestión, y derivó el asunto al juzgado ordinario de segundo voto. Allí Atanasio -que no sabía escribir- empezó a ser representado explícitamente por un tercero. Extensos escritos de su amo dirigidos a las autoridades dejaron entrever que el litigio judicial sería largo. En este contexto, el esclavo solicitó al juez: "a causa del estado miserable en que me hayo y de estar aún bajo su dominio, se ha de servir usted mandar promueva mis derechos el Defensor general de pobres...". De allí en adelante intervinieron en favor del demandante el Procurador de pobres de la Real Audiencia, y tres Defensores de pobres del cabildo. Uno de ellos, Manuel Rodríguez de la Vega, afirmó: “Vélez sabe que Dios y el Rey son contentos de que los siervos lleguen a su libertad, Vélez por fuerza ha de querer lo que Dios y el Rey desean". Al año siguiente, el nuevo Defensor de pobres -Antonio José de Escalada- tomó a su cargo la representación de Atanasio. Pero el esclavo, no contento con su desempeño, exigió que Rodríguez de la Vega continuara patrocinándolo, aclarando que este no había podido rechazar su solicitud, movido de su "innata piedad". Rodríguez de la Vega retomó la defensa del esclavo, ejerciendo una labor comprometida. Lamentablemente el expediente está inconcluso. ${ }^{2}$ Sin embargo, en una demanda unos años después, en apoyo a la solicitud de un esclavo, otro Defensor de pobres mencionaba como antecedente el caso de Joseph Atanasio. ${ }^{3}$ Lo cual nos hace presuponer que hubo una sentencia favorable al esclavo, sentando jurisprudencia para demandas similares en años posteriores.

1 El presente trabajo fue realizado bajo el financiamiento del Consejo Nacional de Investigaciones Científicas y Técnicas (CONICET) de Argentina. Agradezco las agudas observaciones realizadas a versiones preliminares de este artículo en el "III Workshop: Culturas jurídicas en Hispanoamérica" (San Miguel, Argentina, 2017), y en el taller "Post-abolición y Ciudadanía durante el siglo XIX en el Cono Sur", organizado por el Grupo de Estudios Afrolatinoamericanos (Ciudad Autónoma de Buenos Aires, Argentina, 2018). También soy deudor de los enriquecedores comentarios hechos por los evaluadores anónimos de la revista.

2 Archivo General de la Nación (AGN), Sala IX, Tribunales-Expedientes sin letra, 36-1-1, exp. 12, 1777.

${ }^{3}$ AGN, Sala IX, Hacienda, leg. 52, exp. 1351, 1788-1790. 
Esta larga batalla judicial con final feliz revela muchas aristas respecto a la compleja relación que los esclavos ${ }^{4}$ entablaban con las justicias en la época tardocolonial. También dispara múltiples preguntas en torno al tema que es foco de nuestra atención: la intermediación que un agente de justicia en particular -el Defensor de pobres- ejercía entre los esclavos de la ciudad de Buenos Aires y diversas autoridades que detentaban iurisdictio. ¿Quiénes eran los Defensores de pobres? ¿Qué otros roles desempeñaban en la sociedad? ¿Qué modalidades asumía el patrocinio que el Defensor de pobres prestaba a los esclavos? ¿La iniciativa de esta asistencia judicial correspondía al esclavo, al defensor o era una exigencia impuesta por el juez? ¿Por qué algunos esclavos preferían ejercer su propia defensa durante el litigio sin que interviniese este regidor? ¿Qué argumentos desplegaban los Defensores de pobres al representar a los esclavos? ¿Era su desempeño negligente o estaban comprometidos con su labor? ¿Cuán exitosos en los tribunales eran los esclavos asistidos por este agente de justicia? ¿Fueron los Defensores de pobres difusores de ideas contrarias a la esclavitud en segmentos más amplios de la población? ¿O solo intentaron mitigar los abusos a los que daba lugar esta institución? Estos son los interrogantes que buscaremos responder a lo largo del trabajo.

La justicia real ocupó desde épocas tempranas un rol central en el mantenimiento del dominio colonial (Zorraquín Becú, 1952). Administrar justicia, deshacer agravios y amparar a los desvalidos eran tareas íntimamente entrelazadas que se juzgaban esenciales para "mantener en paz un reino". ${ }^{5}$ De esta forma, la arena judicial se transformó en un ámbito en el cual no solo encontraban receptividad los reclamos de las elites, sino también en ocasiones los de variados sectores sociales. Así fue que los indígenas se transformaron en persistentes litigantes ante los tribunales (Borah, 1985; Cutter, 1986; Cunill, 2012; Stern, 1986; Owensby, 2011). Similar estrategia de resistencia y adaptación emplearon los esclavos de diversas regiones y la historiografía ha dado cuenta profusamente de este fenómeno. ${ }^{6}$

Como se vislumbra por los interrogantes que guían nuestra pesquisa, con esta inicial aproximación no pretendemos analizar en su totalidad la relación

\footnotetext{
${ }^{4}$ En adelante cuando hablemos de "esclavos", nos estaremos refiriendo a los hombres y mujeres de origen africano o afrodescendiente que eran catalogados racialmente como "negros/as", "morenos/as", "pardos/as" y "mulatos/as", y que habiendo sido esclavizados eran considerados legalmente propiedad de otra persona.

${ }^{5}$ Definición de desvalido en el Diccionario de la Real Academia Española, (RAE), ediciones de 1732, 1780, 1783, 1791, 1803 y 1817, disponible en: www.rae.es.

${ }^{6}$ La bibliografía al respecto es amplísima. Algunos ejemplos ilustrativos: Owensby, 2005; González Undurraga, 2014; Aguirre, 1995; Scott, 1989; De la Fuente, 2004; Díaz y Meriño Fuentes, 2015; Petit Muñoz, 1947; Gallego, 2005. Para el caso de Buenos Aires, ciudad-puerto que albergaba una numerosa población esclava, contamos con variadas aproximaciones: Levaggi, 1973; Johnson, 2007; Bernand, 2001; Mallo, 1991; Kluger, 2003; Candioti, 2010; Perri, 2009; Casals, 2011; Secreto, 2010; Crespi, 2007.
} 
que los esclavos entablaban con las justicias, sino solo un aspecto de esta temática: el rol desplegado por los Defensores de pobres en los litigios que los esclavos iniciaban contra sus amos. ${ }^{7}$ De esta forma quedarán fuera de nuestra observación la totalidad de los expedientes en los cuales los esclavos eran acusados de haber cometido un delito. Tampoco serán analizadas las solicitudes y los expedientes iniciados por esclavos denunciando a sus amos en los cuales no tenía intervención el defensor. El marco geográfico escogido es la ciudad y campaña de Buenos Aires, ámbito de actuación de los Defensores de pobres nombrados por el cabildo porteño. La delimitación temporal abarca desde la creación del Virreinato del Río de la Plata en 1776, hasta 1810, período en el cual miles de esclavos ingresaron por el puerto de Buenos Aires, como nunca antes (Borucky, 2017: 50). Nuestra mirada tendrá en cuenta -además de cuestiones netamente jurídicas- la posición económica y los roles sociales y políticos desempeñados por los distintos actores que se relacionaban en la arena judicial. ${ }^{8}$ El corpus documental analizado se compone primordialmente de 41 procesos judiciales que se conservan en fondos documentales del Archivo General de la Nación (AGN) y del Archivo Histórico de la Provincia de Buenos Aires (AHPBA).

\section{Los esclavos litigantes}

El total de esclavos asistidos por los Defensores de pobres en nuestra muestra asciende a 74 individuos. Ello se debe a que varias demandas eran colectivas. Los hombres eran mayoría -50- frente a las mujeres -24-. Del total de asistidos, 39 fueron calificados como "negros" o "morenos", y 24 como "pardos" o "mulatos". ${ }^{9}$ Del resto no se explicitó este dato. La mayoría de los peticionantes residían en el casco urbano -43-. En solo cuatro casos los asistidos vivían en la campaña. Un número significativo -17- no residían ni en el área urbana ni en zonas rurales, ya que eran sujetos que habían sido capturados en operaciones de corso. ¿Qué características demográficas, sociales y económicas presentaba la población esclava en su conjunto en el área y períodos delimitados? En Buenos Aires, los individuos catalogados como negros y mulatos durante el período representaron cerca del 30\% de la población y en su gran mayoría eran esclavos

\footnotetext{
7 Los Defensores de pobres asistían también a los encarcelados y a los pobres solemnes (Rebagliati, 2016). En términos generales, los agentes de justicia -como Procuradores o Defensores de pobres- que patrocinaban en este ámbito a diversos sectores han recibido escasa atención por parte de la historiografía. Algunas excepciones en: Zapata de Barry, 2007 y 2013; Pugliese Lavalle, 1996; González Undurraga, 2012; Azevedo, 2007.

8 Esta opción metodológica ha recibido la denominación de "Historia social de la justicia" (Barriera y Polimene, 2010; Palacio, 2005-2006).

9 Los africanos y afrodescendientes esclavizados solían categorizarse a sí mismos como "negros", "morenos" o "pardos" pero no empleaban el término "mulato", dada la connotación denigratoria que tenía este calificativo. Este vocablo era usado por terceros como agentes de justicia, testigos y autoridades.
} 
(Johnson y Socolow, 1980: 333; Goldberg, 1976). La historiografía ha marcado el contraste entre la sociedad porteña y las sociedades de plantación características del Caribe, las colonias inglesas del sur en América del Norte, o partes de Brasil. Buenos Aires no era una "sociedad esclavista" como estas, sino una "sociedad con esclavos". ${ }^{10}$

Es lógico que la mayoría de los esclavos asistidos por los Defensores de pobres en el período hayan residido en la ciudad. Los esclavos urbanos, además de tener más cercanía con las instituciones judiciales, eran mucho más numerosos que los que residían en la campaña (Johnson y Socolow, 1980: 333; Comadrán Ruiz, 1969: 81; Mayo, 2004: 136). En muy pocas ocasiones los litigantes explicitaban el modo en el que se ganaban la vida. Muchos eran esclavos domésticos, pero no faltaban los artesanos -zapateros, plateros, herreros-, panaderos, vendedoras ambulantes, cocineras y lavanderas. Los pocos esclavos rurales eran jornaleros, a excepción de un capataz de estancia. Varios de los asistidos hacían referencia al jornal que debían entregar a sus amos. Este tipo de esclavitud, que ha sido denominada por la historiografía como estipendiaria o a jornal (Saguier, 1989; Andrews, 1989: 37-43), era característica no solo de Buenos Aires sino también de otras ciudades hispanoamericanas. ${ }^{11}$ Los esclavos debían entregar una suma fija de dinero a sus amos en forma diaria. A cambio gozaban de una libertad de movimientos considerable, siempre y cuando cumplieran con dicho pago. Así gozaban de "vías de escape" o "ámbitos de libertad", a veces viviendo bajo un techo distinto al de sus amos, pudiendo disponer de ratos de ocio en pulperías, eligiendo empleador a su gusto e incluso pudiendo ahorrar un peculio propio en pos de comprar su propia libertad o la de sus parientes (Bernand, 2000: 103106; Mallo, 2005: 86). Este deterioro parcial de la condición esclava no dejaba de asombrar a muchos viajeros, que marcaban el contraste con las economías de plantación (Rebagliati, 2014). Sin embargo, los esclavos a jornal eran explotados a fin de cuentas, no dejaban de estar expuestos a los maltratos de sus amos, y quienes lograban comprar su propia libertad eran una minoría (Johnson, 1979). Pese a que existía una significativa heterogeneidad socio-ocupacional entre los esclavos, también era claro en la época que todos los que se hallaban comprendidos dentro de este particular estatus jurídico, compartían un mismo "estado" o "condición", y eran parte de una misma "clase". ${ }^{12}$ Un procurador de la Audiencia se quejó del deseo de los esclavos por sacudirse el "yugo de la

\footnotetext{
${ }^{10}$ La diferenciación conceptual entre una "sociedad esclavista" y una "sociedad con esclavos" en Finley, 1982: 84-108. Esta caracterización de la sociedad porteña ha sido planteada posteriormente por varios autores. Entre ellos: Mallo, 2005; Goldberg, 2005.

${ }^{11}$ Se ha sostenido que en Hispanoamérica "una complicada trama de propiedad, alquiler y empleo por cuenta propia, convirtió, pues, a los esclavos en una fuerza de trabajo sumamente móvil y adaptable" (Klein, 1986: 31).

12 AGN, Sala IX, Tribunales-Expedientes con letra, 41-3-3, exp. 15, 1796. AGN, Sala IX, Tribunales-Expedientes sin letra, 36-5-1, exp. 5, 1786.
} 
servidumbre". ${ }^{13}$ Una vecina, enfurecida por los reclamos de sus siervos en la justicia, llegó a calificar a los esclavos como "las personas más viles de un pueblo". ${ }^{14}$ Los esclavos litigantes resaltaban el infortunio y las desdichas que sufrían en virtud de su situación, calificándose como "desvalidos", "afligidos", "desamparados", o "infelices".

\section{Un "honorífico empleo"}

El oficio de Defensor de pobres fue creado en el seno del ayuntamiento porteño en 1721. En el período virreinal dicho cargo era asignado a uno de los regidores, tenía un carácter rotativo -de duración anual-, y su desempeño era gratuito ya que era concebido como una carga pública. Estos regidores eran los encargados de representar a los esclavos en primera instancia ante los juzgados ordinarios del cabildo. Si las sentencias de esta instancia eran apeladas, a partir de allí los esclavos pasaban a ser patrocinados por el Procurador de pobres de la Real Audiencia. Este último cargo era letrado, rentado y tenía más estabilidad en el tiempo que los defensores del cabildo.

A lo largo del período estudiado, 36 personas ocuparon el oficio de Defensor de pobres. En ocasiones, la historiografía se ha referido a ellos como "abogados ilustrados" (Bernand, 2000: 106). Sin embargo, todos eran legos, ya que ninguno de ellos había estudiado formalmente leyes. Ello fuera impedimento para que desempeñaran la función, ya que la cultura jurídica de la época excedía con creces a los letrados (Agüero, 2005). ${ }^{15}$ La mayoría de ellos $24-$ asistieron a esclavos que llevaron sus reclamos a los tribunales. ${ }^{16}$ Estos regidores eran un reflejo bastante fiel de la elite local, siendo algunos de ellos los comerciantes mayoristas más ricos y prestigiosos de la ciudad (Rebagliati, 2016). Como tales, era común que poseyeran esclavos. En 1778, entre los sujetos que en años posteriores iban a ser Defensores de pobres, se destacaban como propietarios de esclavos Francisco Antonio Escalada y Francisco Castañon ambos con 13-, Saturnino Saraza con 10, y Antonio García López con 7. Otros en cambio eran propietarios más modestos, como Manuel Arana, Francisco Ignacio de Ugarte o Manuel Rodríguez de la Vega, todos ellos con 4 esclavos cada uno. Otros futuros Defensores de pobres no poseían ni un solo esclavo en el mismo año, como Martín de Álzaga, Juan de Llano, o Antonio José Escalada. ${ }^{17}$ Pero ello se debía a que eran jóvenes solteros que recién estaban iniciándose en

\footnotetext{
${ }^{13}$ AGN, Sala IX, Tribunales-Expedientes sin letra, 36-5-1, exp. 5, 1786.

${ }^{14}$ AGN, Sala IX, Tribunales-Expedientes sin letra, 36-8-4, exp. 6, 1780.

${ }^{15}$ De todas formas, los Defensores de pobres contaron con asesores letrados durante el período (Pugliese, 2000).

${ }^{16}$ No tenemos forma de saber si el resto de los Defensores de pobres no asistieron a esclavos, o si efectivamente lo hicieron pero dichos expedientes ya no se conservan en los archivos.

${ }^{17}$ Documentos para la historia argentina. Vol. XI. Territorio y población: Padrón de la ciudad de Buenos Aires (1778) (1919), Buenos Aires: Facultad de Filosofía y Letras, Universidad de Buenos Aires.
} 
el comercio mayorista. Pasadas tres décadas, en 1810, la situación era muy distinta, ya que habían incrementado considerablemente la cantidad de esclavos que poseían. ${ }^{18}$ ¿Se contaban los individuos que fueron Defensores de pobres entre los mayores propietarios de esclavos de la sociedad porteña de la época? Podemos decir que en el cenit de sus carreras generalmente sí. Según el censo de 1778, los comerciantes más destacados de la ciudad solían tener entre diez y quince esclavos. Solo unos pocos individuos eran propietarios de más de 20. ${ }^{19}$ Además de ser propietarios de esclavos, en algunos casos los Defensores de pobres practicaban el tráfico de esclavos. Este era el caso de Tomás Antonio Romero, el mayor comerciante de esclavos del Virreinato del Río de la Plata. ${ }^{20}$ Otros Defensores de pobres que fueron protagonistas de la trata negrera fueron Francisco Beláustegui, Martín de Álzaga y Diego Agüero (Borucki, 2011). ${ }^{21}$

Es evidente que en términos sociales los Defensores de pobres tenían mucho más en común con los contrincantes legales con los cuales debían litigar que con sus asistidos. El esclavo Ildefonso Muñoz dirigió varias peticiones al alcalde de primer voto, y en una de ellas aclaró que su escrito “...no ba por mano del defensor de pobres porque es pariente de mi amo por lo que espero se admita sin reparo...".22 De algunos Defensores de pobres nos han quedado rastros sobre sus ideas y comportamientos sobre la institución de la esclavitud en general y sobre los esclavos de su propiedad en particular. Antonio García López, quien llegó a tener 10 esclavos, en su testamento los liberó a todos, dejándoles regalos en dinero (Socolow, 1991: 98-107). En el extremo opuesto puede situarse a Francisco Ignacio Ugarte, quien en una sesión del cabildo hizo un fuerte alegato en contra de las libertades que tenían negros y mulatos -libres y esclavos- para protagonizar bailes que incluso ya habían sido autorizados por el Virrey. En su opinión la "religión", el "estado" y el "público" se veían perjudicados por esta práctica, que vulneraba "las leyes humanas y divinas". Sostenía que por culpa de los bailes los esclavos "no sirven a sus amos con

\footnotetext{
${ }_{18}$ AGN, censo de 1810: legajo 10-7-1.

${ }^{19}$ En comparación con las sociedades de plantación esclavistas, estos números pueden parecer irrisorios. Thomas Jefferson, autor de la declaración de independencia de los Estados Unidos donde entre otras cosas sostenía que "todos los hombres son creados iguales"- en 1781 era propietario de al menos 200 esclavos (Morgan, 2009: 419).

${ }^{20}$ Lyman Johnson, ha aseverado que Tomás Antonio Romero durante el año que ejerció la defensoría de pobres no representó judicialmente a ningún esclavo (Johnson, 2007: 637). Sin embargo, nosotros hemos encontrado algunas intervenciones de este tipo que lo tienen como protagonista. AGN, Sala IX, Tribunales con letra, 41-1-1, exp. 13, 1797. AGN, Sala IX, Tribunales con letra, 40-4-6, B 8, exp. 13, 1798. AGN, Sala IX, Tribunales-expedientes sin letra, 37-3-6, leg. 128, exp. 1, 1799. AHPBA, Juzgado del crimen, 34-2-24-21, 1799. AHPBA, Juzgado del crimen, 34-2-24-37, 1799.

21 La actividad de compra-venta de esclavos de Diego Agüero fue estudiada por Mariano Schlez, quien sostiene que esta actividad era secundaria en el volumen de negocios de este gran comerciante mayorista (Schlez, 2016).

22 AGN, Sala IX, Tribunales con letra, 41-8-3, exp. 13, 1798.
} 
fidelidad" y que aprovechaban la ocasión para recaudar dinero en pos de obtener la ansiada libertad. En su opinión esto último "no pueden hacerla de otro modo, que robándola a sus amos". ${ }^{23}$

Tampoco faltaron los Defensores de pobres -que antes o después de ocupar el cargo- fueron denunciados por malos tratos a sus esclavos. Francisco Escalada primero fue denunciado por haber reprendido severamente a una esclava suya por una nimiedad, y luego haberla recluida injustificadamente en la Casa de la Residencia. ${ }^{24}$ Un año después Manuel Escobar -otro de sus esclavos- se quejó al Virrey de que Escalada lo acusaba injustamente de un robo acontecido en su casa. Agregaba además que no le proporcionaba vestuario suficiente. ${ }^{25}$ Cecilio Sánchez de Velazco había sido defensor en 1778. En 1797 sufrió la demanda del Defensor de pobres José Santos de Inchaurregui, quien representaba a las esclavas María Josefa y su hija. ${ }^{26}$ Quien había sido Defensor de pobres, ahora estaba situado en el lugar de amo denunciado, intentando refrenar las aspiraciones de libertad de sus propios esclavos. En breve veremos cómo algunos Defensores de pobres en el ejercicio de su función a veces socavaron la legitimidad de la esclavitud, mediante argumentos tradicionales o ideales ilustrados. ${ }^{27}$ Es claro que la posición que los Defensores de pobres detentaban en la sociedad no determinaba a priori el desempeño que exhibían en su función. Pero no es menos cierto que el hecho de que todos eran propietarios de esclavos -estando algunos de ellos implicados en la trata atlántica-, desmiente la idea de que fueran denodados antiesclavistas.

\section{El mundo jurídico de la esclavitud}

Reconstruir el corpus normativo que regulaba la vida de los esclavos en los dominios hispanos, y específicamente en Buenos Aires, no es tarea sencilla. No solo por la naturaleza casuista, acumulativa y fragmentaria de la legislación dictada por distintas autoridades sobre la materia. ${ }^{28}$ Sino también porque el

\footnotetext{
23 Acuerdos del extinguido Cabildo de Buenos Aires (1925-1933), Serie III, Tomo VIII, Buenos Aires: Kraft, pp. 627-630.

${ }^{24}$ AGN, Sala IX, Solicitudes de esclavos, 13-1-5. 6 de noviembre de 1777.

${ }^{25}$ AGN, Sala IX, Solicitudes de esclavos, 13-1-5. 17 de febrero de 1778.

26 AHPBA, Civil Provincial, 5.3.47.2, 1797. Un relato y transcripción completa de este caso en Zapata de Barry, 2013: 123-150.

27 Este aspecto ha sido resaltado por la historiografía. Carmen Bernand asevera que "El Defensor de pobres, en el último tercio del siglo XVIII, desempeñó un papel considerable en la propagación de las ideas liberales hostiles a la esclavitud o por lo menos, a los abusos de la institución" (Bernand, 2000: 106). Zapata de Barry comparte este juicio: "Secundado legalmente por abogados de la época, a fines del siglo XVIII se constituyó en vocero de las ideas contrarias a la esclavitud y a los abusos de la institución" (Zapata de Barry, 2013: 24).

28 En el presente apartado solo reseñaremos las normas relativas a los derechos y deberes de los esclavos. Dejaremos de lado las referentes a la represión de los levantamientos, las huidas y el
} 
derecho de Antiguo Régimen estaba lejos de restringirse a las normas escritas, y admitía otras fuentes como las obras doctrinales, la jurisprudencia, la costumbre, ciertos preceptos bíblicos, etc., otorgando un margen de maniobra importante a los jueces (Agüero, 2006; Tau Anzoátegui, 2001). Sin embargo, la historiografía ha ahondado fructíferamente en esta cuestión desde hace décadas. ${ }^{29}$ El cuerpo legislativo más abarcativo sobre la esclavitud lo constituían Las siete partidas de Alfonso el sabio, que pese a haber sido dictadas en el siglo XIII, conservaban toda su vigencia a fines del siglo XVIII. ${ }^{30}$ También se destacaba la Real Cédula de Su Majestad sobre la educación, trato y ocupaciones de los esclavos, en todos sus dominios de Indias e Islas Filipinas, dictada por el rey en 1789, la cual recogía y sistematizaba normas y costumbres que regían desde antaño (Torre Revello, 1961; Levaggi, 90-91; Lucena Salmoral, 2000: 359). ${ }^{31}$ Podemos coincidir con la pionera aseveración de Eugenio Petit Muñoz. En los dominios hispanoamericanos "el esclavo era una cosa con supervivencias crecientes de persona". Al ser considerado una cosa podía ser objeto de compra, venta, alquiler, herencia, expropiación, contrabando, hipoteca, embargo, depósito, etc. Pero también tenía ciertos derechos y obligaciones derivados de su condición de persona (Petit Muñoz, 1947). En las partidas se afirmaba que la libertad era el estado natural de todos los hombres, y que la esclavitud era un producto histórico. ${ }^{32}$ ¿Cuáles eran estos derechos y obligaciones?

El más importante de ellos era el derecho a la vida. Los amos no podían matar a sus esclavos. En caso de hacerlo podían recibir la misma pena que les correspondía si la víctima hubiera sido libre. ${ }^{33}$ Los esclavos también tenían derecho al buen trato. Sus amos no solo debían vestirlos y alimentarlos adecuadamente, sino que además no debían infligirles castigos físicos excesivos. En caso de no cumplir con estas obligaciones se exigía al amo la venta de su esclavo por un precio fijado por el juez. ${ }^{34}$ Los esclavos no podían ser obstaculizados en su deseo de matrimonio, pudiendo concretarlo con personas libres. ${ }^{35}$ También podían participar de la vida religiosa, integrando cofradías,

cimarronaje. Tampoco analizaremos aquellas prohibiciones y restricciones destinadas a esclavos y libertos tendientes a garantizar su subordinación social, económica y jurídica.

${ }^{29}$ Al respecto se destacan: Petit Muñoz, 1947; Gallego, 2005; Lucena Salmoral, 2000.

${ }^{30}$ Muchos autores han postulado la vigencia de las partidas como derecho vigente referido a la esclavitud hispanoamericana. Entre ellos: García Gallo, 1980; Lucena Salmoral, 1995; Zapata de Barry, 2013: 43-57.

${ }^{31}$ Real Cédula de Su Majestad sobre la educación, trato y ocupaciones de los esclavos, en todos sus dominios de Indias e Islas Filipinas, extraído de Levaggi, 1973: 160-168.

${ }^{32}$ Las siete partidas del rey Don Alfonso el Sabio, cotejadas con varios códices antiguos, por la Real Academia de la historia (1807). Tomos I, II y III, Madrid: Imprenta Real. Tomo III, Partida IV, Título XXI, Ley I.

${ }^{33}$ Las siete..., Tomo III, Partida IV, Título XXI, Ley VI. Tomo III, Partida VII, Título VIII, Ley II.

${ }^{34}$ Las siete..., Tomo III, Partida IV, Título XXI, Ley VI. Real Cédula..., cap. VIII.

${ }^{35}$ Las siete..., Tomo III, Partida IV, Título V, Ley I y II. 
siendo bautizados, oyendo misa y asistiendo a las fiestas. ${ }^{36}$ La manumisión era otro de los derechos que operaba bajo ciertas circunstancias. Por donación del amo, por testamento, o por una serie de causas ajenas a la voluntad del amo. ${ }^{37}$ De todas formas los esclavos liberados no se equiparaban a los hombres libres, sino que eran libertos, una categoría intermedia (Crespi, 2010). ${ }^{38}$ La forma más usual de liberación de los esclavos en la América Hispana fue la autocompra de su propia libertad. Este derecho, durante mucho tiempo no reconoció un explícito fundamento en las leyes sino en las costumbres, hasta que empezó a ser legislado a mediados del siglo XVIII, pero solo para Cuba. ${ }^{39}$

¿Cómo hacían los esclavos para intentar que se respetaran estas prerrogativas? Tenían derecho a la asistencia judicial. En casos de malos tratos o desconocimiento de su libertad estaban habilitados para presentarse a los tribunales por cuenta propia, o por medio de terceros. ${ }^{40}$ Junto con los presos, los pobres solemnes, las viudas y los huérfanos, eran calificados como pobres y miserables. ${ }^{41}$ Sus litigios eran considerados casos de corte y podían ser tramitados ante la Real Audiencia, Gobernadores o Virreyes, ya que dicha calificación implicaba el privilegio para el querellante de poder elegir ante que autoridad de justicia presentaba su demanda. Además contaban como hemos dicho con el patrocinio jurídico gratuito brindado por ciertos regidores de los ayuntamientos -Defensores de pobres, Síndicos Procuradores- y por funcionarios de las Reales Audiencias -Procuradores de pobres-. ${ }^{42}$ Los esclavos también tenían obligaciones que cumplir. La esclavitud era una de las cinco formas de señorío y vasallaje existentes. Por su condición no podían disponer libremente de su

\footnotetext{
${ }^{36}$ Recopilación de leyes de los Reinos de las Indias mandadas a imprimir y publicar por la majestad católica del Rey Don Carlos II Nuestro Señor (1841). Tomos I y II, Madrid: Boix. Libro I, Título IV, Ley XXV. Libro I, Título I, Ley XII y XVII. Según Petit Muñoz, en estas normas hay un reconocimiento del derecho de asociación bajo ciertas condiciones, y el derecho al ocio, ya que los esclavos no debían trabajar los domingos ni los días de fiestas religiosas. La Real Cédula de 1789 estableció que dos horas diarias debían ser reservadas a los esclavos "en su personal beneficio y utilidad". Real Cédula..., cap. III.

${ }^{37}$ Las siete..., Tomo III, Partida IV, Título XXII, Ley I, II, III, IV, V, VI, VII. Tomo II, Partida III, Título XXII, Ley XXVIII.

${ }^{38}$ Las siete..., Tomo III, Partida IV, Título XVI, Ley V. Tomo III, Partida IV, Título XXII, Ley VIII, IX, X y XI. Tomo II, Partida III, Título VII, Ley IV. Tomo II, Partida III, Título XVI, Ley X.

${ }^{39}$ Allí se denominaba coartación, e incluía el pago en cuotas y el congelamiento del precio una vez hecho el primer pago (Lucena Salmoral, 1999; De la Fuente, 2007; Obando Andrade, 2011). ${ }^{40}$ Las siete..., cit., Tomo III, Partida IV, Título XXI, Ley VI. Tomo II, Partida III, Título II, Ley VIII. 41 AGN, Sala IX, Tribunales-Expedientes con letra, 42-8-5, exp. 15, 1778. AGN, Sala IX, Tribunales-Expedientes sin letra, 35-7-1, exp. 22, 1779. En la Capitanía General de Chile en la misma época la mayoría de los litigios iniciados por esclavos ante la Real Audiencia eran presentados como "casos de corte", privilegio reservado a los miserables (González Undurraga, 2014: 21).

${ }^{42}$ Recopilación de..., Tomo II, Libro VII, Título V, Ley VIII. Real Cédula..., cap. XIII.
} 
persona, debiendo servir y obedecer a sus amos. Caso contrario podían ser castigados y golpeados "correccionalmente". ${ }^{43}$

El ordenamiento jurídico hispanoamericano relativo a la esclavitud era muy distinto al que imperaba en colonias de otras potencias. Por ejemplo, la legislación francesa e inglesa -en particular esta última- se caracterizaban por conceder pocos derechos a los esclavos, obstaculizando considerablemente la posibilidad de que consiguieran la libertad (Gallego, 2005). La constatación de este fenómeno ha disparado nutridos debates desde mediados del siglo pasado. ${ }^{44}$ Algunos autores sostienen que las leyes hispanas efectivamente eran aplicadas y reflejaban la benignidad con que eran tratados los esclavos en Hispanoamérica en comparación con sus colegas de los dominios de otros países. Otros en cambio postulan que las leyes eran letra muerta y que el trato recibido por los esclavos estaba condicionado por otros factores, señalando la inexistencia de diferencias sustanciales entre distintas regiones. Sin caer en estos extremos, se puede pensar que las leyes indianas en ciertos casos brindaron una vía por medio de la cual los esclavos pudieron resistir, adaptarse, y desafiar las prácticas y el poder de sus amos. Así lograron mitigar abusos o conseguir la libertad en algunos casos, transformando derechos abstractos en conquistas concretas, como ha afirmado Alejandro de la Fuente. ${ }^{45}$ Ello explica por qué en numerosas colonias hispanoamericanas acudieron a los tribunales con frecuencia. Los esclavos de Buenos Aires no fueron la excepción.

\section{Los Defensores de pobres entran en escena}

Muchos esclavos optaban por presentar sus quejas directamente al Virrey, eludiendo al juzgado ordinario del Cabildo, y prescindiendo del patrocinio de los Defensores de pobres. ${ }^{46}$ ¿Quiénes escribían estos memoriales? Se ha aseverado que "el Defensor de pobres redactaba las solicitudes y las dirigía al Virrey" (Bernand, 2000: 106). Sin embargo, lo creemos poco probable. Ninguna de las solicitudes fue firmada por los Defensores de pobres. Unas pocas fueron firmadas por los mismos esclavos, en otros casos escasos aparece la firma de otro sujeto "a ruego del suplicante" y el resto de las solicitudes no fueron firmadas por nadie. En los cientos de documentos producidos por los Defensores de pobres, siempre en el encabezado se aclaraba que ellos eran los

${ }^{43}$ Las siete...., Tomo III, Partida IV, Título V. Tomo III, Partida IV, Título XXV, Ley II. Tomo III, Partida IV, Título XXI, Ley V. Tomo III, Partida IV, Título XXI, Ley VI. Real Cédula...., cap. VIII.

${ }_{44}$ Concretamente desde la aparición de la clásica obra de Frank Tannembaum en 1946 (Tannembaum, 1972). Para un resumen de los debates suscitados ver De la Fuente, 2004.

${ }^{45}$ Esta postura, heredera de los planteos de Tannembaum, reconoce el impacto que el régimen jurídico podía tener en la vida de los esclavos pero atiende a las diferencias regionales y cronológicas, además de considerar otros factores, a modo de evitar generalizaciones (Klein, 1967; Lucena Salmoral, 2000; Gallego, 2005; De la Fuente, 2004).

${ }^{46}$ AGN, Sala IX, Solicitudes de esclavos, 13-1-5. 
autores del texto, apareciendo al final su firma. En segundo término, si bien los Defensores de pobres de fines de la colonia no eran letrados, estaban familiarizados con la escritura y redacción, lo que se evidencia en una escritura prolija, firme y cuidada, donde se exponían complejas argumentaciones jurídicas. Los memoriales en muchos casos exhiben una escritura que posee pocas de estas características. Es probable que quienes prestaban su pluma en servicio de los esclavos fuesen terceros que tenían algún vínculo -familiar, de amistad o compadrazgo- con ellos, simples conocidos, o sujetos que se ganaban la vida redactando memoriales a otras personas a cambio de un poco de dinero.

Al dirigir sus peticiones al Virrey, evitaban ser juzgados por los alcaldes de primer y segundo voto, quienes podían tener estrechos lazos comerciales, familiares, de amistad y de clase con sus respectivos amos. El esclavo José Gimenez denunció al Virrey que cuando quiso llevar su reclamo al juzgado del cabildo vio "despreciada mi solicitud por el señor alcalde, que devolvió el expediente con la expresión de que estaba cansado de administrar justicia a los de mi clase...". ${ }^{47}$ Pero los virreyes en una alta proporción optaban por derivar estas quejas de los esclavos a los alcaldes ordinarios del ayuntamiento. Sin embargo, los Defensores de pobres estaban lejos de monopolizar la representación de los esclavos en las causas tramitadas en estos juzgados de primera instancia. De 102 expedientes judiciales de este tipo que hemos localizado en los archivos, estos defensores intervinieron solo en 41 de ellos. ¿Quiénes patrocinaban a los esclavos cuando el Defensor de pobres no intervenía? La mayoría de las veces un tercero redactaba sus escritos a ruego. En otras ocasiones los escritos aparecen sin rúbrica, firmaban ellos mismos o aparece explícitamente otra persona identificable como un familiar o los Procuradores de pobres de la Real Audiencia. ${ }^{48}$ Algo curioso a resaltar, es que un poco menos de la mitad de las causas en las que intervenían los Defensores de pobres no eran iniciadas por presentaciones de estos regidores sino por escritos que los esclavos -firmados por ellos mismos o por un tercero "a ruego"- dirigían casi exclusivamente al Virrey. El Virrey luego derivaba el asunto a la justicia ordinaria y, en algún momento del proceso, los Defensores de pobres tomaban intervención. El resto de las causas se iniciaban directamente con un escrito del Defensor de pobres. Estos escritos de los defensores estuvieron dirigidos al juzgado ordinario en doce ocasiones y al

47 AGN, Sala IX, Tribunales-Expedientes con letra, 41-3-3, exp. 15, 1796. Un caso similar en AGN, Sala IX, Tribunales-Expedientes con letra, 42-1-7, exp. 10, 1788.

${ }^{48}$ Lyman Johnson brinda una interpretación diferente al aseverar que la mayoría de los esclavos acudían al defensor a la hora de iniciar la demanda. En palabras del autor "most commonly the defensor -and avocacy position usually filled by one of the cabildo's regidores, or occasionally an alcalde- represented the plaintiff." En otro párrafo se refiere a este oficio como el "defensor general de pobres, indios y esclavos" (Johnson, 2007: 632). Pero los indios eran asistidos por el Protector de naturales, salvo casos muy excepcionales. 
Virrey solo cinco veces. Un escrito fue dirigido al Gobernador, otro a un Oidor y otro al Juez Comisionado de Marina.

Los procesos en los cuales el defensor entraba en escena una vez comenzado el litigio -y no desde el principio- son ricos porque nos permiten discernir si la asistencia de los Defensores de pobres era requerida por los mismos esclavos, o si se trataba de una determinación de los alcaldes ordinarios. La situación más común parece haber sido aquella en la cual el patrocinio del defensor era decidido o aconsejado por el magistrado interviniente. A veces el Virrey era el que daba intervención al Defensor de pobres. Cuando Josef Pacheco denunció en un memorial que sufría "un tratamiento inhumano de su amo", el Virrey resolvió: "llevesé al Defensor de pobres para que cerciorándose de lo que hay de verdad en esta relación me informe y produzca los testigos con que debe manifestarse para que se haga justicia". ${ }^{49}$ En otras ocasiones la disposición provenía de los alcaldes ordinarios. ${ }^{50}$ Pero a veces, la asistencia del Defensor de pobres era solicitada por los mismos esclavos. ${ }^{51}$ El defensor Antonio José de Escalada informó al alcalde de segundo voto que la mulata esclava María Josefa le había rogado que escribiese un petitorio en su nombre. El defensor explicó que: "valiéndose esta pobre de el defensor e implorando su noble y piadoso oficio le ha instado para que a su nombre haga a este fin instancia...". ${ }^{52}$ Otro esclavo, llamado Juan Ximenez, litigaba contra su ex amo acerca de la propiedad de una manada de caballos. En su escrito al Virrey requirió: "se ha de servir V. E. mandar se me oiga en justicia y que se encargue de mi defensa el defensor de pobres". ${ }^{53}$ Una tercera vía -excepcional- era aquella situación en la cual el patrocinio del defensor no se originaba de una disposición del juez, ni de una iniciativa de los esclavos querellantes, sino de la misma preocupación del Defensor que actuaba "de oficio" ante una situación que había llegado a oídos suyos. ${ }^{54}$

¿Intentaron excusarse los Defensores de pobres de asistir a los esclavos? En unas pocas ocasiones sí. En una causa, cuando el escribano fue a notificarle un escrito de la otra parte al defensor Manuel de Arana, este "expuso en el acto no deberse entender con el esta causa por no ser de las que corresponden a su

\footnotetext{
${ }^{49}$ AGN, Sala IX, Tribunales-Expedientes sin letra, 36-4-6, exp. 7, 1780. La orden a veces podía ser verbal y no haber dejado rastros, salvo en aquellos casos en los que el defensor explicitaba esta situación posteriormente. AHPBA, Juzgado del Crimen, 34-2-24-37, 1799.

${ }^{50}$ AGN, Sala IX, Tribunales-Expedientes con letra, 42-4-6, exp. 1, 1787. AHPBA, Juzgado del Crimen, 34-2-24-21, 1799.

${ }^{51}$ AGN, Sala IX, Tribunales-Expedientes sin letra, 36-1-1, exp. 12, 1777.

${ }^{52}$ AGN, Sala IX, Tribunales-Expedientes con letra, 40-8-2, exp. 1, 1780.

${ }^{53}$ AGN, Sala IX, Tribunales-Expedientes con letra, 41-3-3, exp. 15, 1796. Seguramente no quería estar en desventaja frente a su ex amo, quien era asistido por Juan José Castelli, un joven abogado que luego se convertiría en uno de los más notables y radicalizados dirigentes revolucionarios (Wasserman, 2011: 35).

${ }^{54}$ AGN, Sala IX, Tribunales-Expedientes sin letra, 36-8-4, exp. 12, 1785.
} 
protección". ${ }^{55}$ El defensor Tomás Antonio Romero también trató de abstenerse de actuar en una causa, sin fundamentar su pedido, pero el juez hizo caso omiso de la solicitud. ${ }^{56}$ Quien brindó muchos más argumentos para eximirse de representar a unos esclavos fue el defensor Gabriel Real de Azúa, quien aseveró que solo le correspondía representar a los encarcelados según las ordenanzas capitulares. Atribuía el patrocinio a los esclavos como una práctica de algunos defensores que actuaron "movidos de su celo". ${ }^{57}$ ¿Estaba en lo cierto el defensor al decir que la asistencia a los esclavos no era parte de sus obligaciones? Las Ordenanzas capitulares de 1695 solo establecían que un regidor tenía que intervenir en los procesos criminales en los cuales se hallaban inmersos los encarcelados. Sin embargo, también era cierto que los esclavos formaban parte de los miserables merecedores de asistencia judicial. Así fue qué pese a que ninguna norma específica establecía que el Defensor de pobres debía asistir a los esclavos, estos regidores efectivamente los patrocinaron durante el período bajo estudio. No solo porque eran piadosos, sino porque concebían que esta era una de las obligaciones inherentes al oficio. De hecho en muy pocas ocasiones los amos denunciados impugnaron la legitimidad de este patrocinio, sin éxito. ${ }^{58}$

¿Cuándo terminaba la asistencia judicial brindada por los Defensores de pobres? En algunos casos duraba hasta el final del litigio. Pero en otros, la relación entablada entre los esclavos y el Defensor de pobres se interrumpía antes. A veces, esta situación era esperable, dado que cuando la sentencia era apelada correspondía a los Procuradores de pobres de la Real Audiencia seguir patrocinando a los esclavos. ${ }^{59}$ Pero en otros casos, los esclavos se veían defraudados por el desempeño de los defensores y revocaban la representación que habían delegado en ellos. El defensor Antonio José de Escalada fue recusado por el esclavo Joseph Atanasio pero también por otra asistida suya, Agustina de los Ríos. Esta esclava primero intentó que el Defensor cesara en su representación "dejándolo en su buena opinión y fama". Pero en un escrito posterior dejó los buenos modales de lado y denunció la complicidad del defensor con su ama afirmando que "ha querido la desgracia y su poca suerte que aquel se haya portado en la actualidad no como defensor de la suplicante si como fiscal de sus operaciones... ${ }^{60}$ Otras veces, esta situación de complicidad entre el defensor y los amos de los esclavos no era tan clara. Pero aun así se producían desacuerdos entre los defensores y sus asistidos. ${ }^{61}$ Lo más común

\footnotetext{
55 AGN, Sala IX, Tribunales-Expedientes con letra, 42-4-6, exp. 1, 1787.

${ }^{56}$ AGN, Sala IX, Tribunales-Expedientes con letra, 40-4-6, exp. 13, 1798.

57 AGN, Sala IX, Administrativos, 23-5-3, exp. 240, 1802.

58 AGN, Sala IX, Tribunales-Expedientes sin letra, 37-3-6, exp. 1, 1799. AHPBA, Criminal Provincial, 5.5.76.2, 1807.

${ }^{59}$ Un caso de este tipo en AHPBA, Civil Provincial, 5.4.60.19, 1794.

60 AGN, Sala IX, Tribunales-Expedientes sin letra, 36-8-4, exp. 6, 1780.

61 AGN, Sala IX, Tribunales-Expedientes con letra, 40-8-3, exp. 12, 1793. AGN, Sala IX, Tribunales-Expedientes sin letra, 36-8-4, exp. 12, 1785.
} 
que ocurría en estos casos era que ante una primera sentencia adversa a los esclavos, los defensores considerasen cumplida su labor y no volviesen a redactar ningún escrito. Los esclavos, en cambio, deseosos de remontar este primer revés, proseguían la causa por otros medios, ya sea consiguiendo que un tercero les firmara sus escritos o logrando que un abogado los representase hasta agotar todos los recursos judiciales disponibles. ${ }^{62}$

\section{Naturaleza y características del patrocinio jurídico}

¿Qué motivos impulsaban a los esclavos asistidos por los Defensores de pobres a dirigirse a los estrados? Estaban quienes decían ser maltratados de distintos modos por sus dueños -22\%-. En una idéntica proporción se encontraban los esclavos que decían haber sido esclavizados injustamente $-22 \%-$. Le seguían de cerca $-19,5 \%$ - los esclavos que decían tener derecho a comprar su propia libertad o a ser adquirido por un tercero por un precio justo sin que mediara ninguno de las causales previstas por la legislación y en contra de la voluntad del amo. Varios esclavos reclamaban su libertad, ya sea por disposición testamentaria $-9,75 \%-$, o por simple promesa del amo $-9,75 \%-.{ }^{63}$ ¿Con qué argumentos los defensores ejercieron su labor en beneficio de sus asistidos? Había aspectos de la relación amo-esclavo que parecían ser incontrovertibles para todos. Es decir que existía cierto consenso entre esclavos, defensores, amos y magistrados sobre algunas de las obligaciones asimétricas que debían caracterizar a la esclavitud, al menos discursivamente. ${ }^{64}$ Difícilmente un amo podía alegar que no era su obligación vestir y alimentar a su esclavo. Tampoco podía reclamar el derecho a maltratarlo severamente. Por supuesto que existían casos de esclavos golpeados o subalimentados. Pero la estrategia de los amos consistía en negar los hechos, porque una vez comprobados los mismos no tenían forma de justificar su accionar. Por ello, en las causas por maltratos, la estrategia de los Defensores de pobres fue producir prueba en favor de sus asistidos y recordar lo señalado por las leyes. También varios apelaban a una comparación entre el derecho romano y el indiano. Mientras el primero en sus inicios se caracterizaba por el poder ilimitado de amos sobre sus esclavos, las leyes dictadas por los reyes católicos con posterioridad penaban los castigos

62 AGN, Sala IX, Tribunales-Expedientes con letra, 42-8-5, exp. 15, 1778. AGN, Sala IX, Tribunales-Expedientes sin letra, 37-3-6, exp. 1, 1799. AHPBA, Criminal Provincial, 7.1.83.19, 1810.

${ }^{63} \mathrm{El}$ resto de las demandas de los esclavos eran variadas. Exigían que se respetara el derecho al peculio, a casarse, a ser declarados hijos naturales, a no ser encarcelados injustamente, discutían ciertas cláusulas de libertad condicional, y un esclavo reclamó su libertad por su desempeño durante las Invasiones Inglesas.

${ }^{64}$ Una autora ha denominado a estos acuerdos como una "economía moral de la esclavitud" (Secreto, 2010: 27-62) 
excesivos. ${ }^{65}$ La solicitud de los defensores consistía en pedir el papel de venta a un precio moderado para que sus asistidos pudiesen cambiar de amo, como establecían las partidas. En una ocasión uno de los defensores fue aún más lejos, ya que solicitó la libertad de la esclava y el procesamiento del ama en virtud de que había tenido intención de matarla. ${ }^{66}$

Las demandas de sujetos que debían haber sido esclavizados injustamente también compartían la característica de que lo que estaba en discusión primordialmente eran los hechos ocurridos, ya que si se lograba demostrar que alguien era libre y había sido sometido a servidumbre en forma ilegítima, las leyes eran claras al respecto. Había que liberarlo. Gerónimo Villanueva comandaba un bergantín de corso, se había apropiado de varios buques portugueses y al mismo tiempo apresaba a la tripulación e intentaba vender como esclavos a negros que en realidad eran libres. ${ }^{67}$ Los Defensores de pobres se encargaron de resaltar que el hecho de que no declararan en su momento que eran libres no era justificativo para que Villanueva los esclavizara, "como si esta omisión en aquel acto fuera capaz de privarles del derecho más recomendable". ${ }^{68}$ También producían prueba y describían la situación de desamparo en al que se hallaban sus asistidos. Aseveraban que ante la duda de si un sujeto era libre o esclavo, debía optarse por concederle la libertad. El defensor Manuel Ortiz de Basualdo aseveró que el accionar de Villanueva era contrario a"...a los privilegios dispensados por derecho a la libertad conforme a los sentimientos de la naturaleza y la equidad para favorecerla en todas circunstancias...". ${ }^{69} \mathrm{El}$ mismo regidor luego se encargó de reafirmar la preferencia que debía observarse por la libertad en caso de incertidumbre al decir que "...en el derecho ha sido siempre tan favorable la causa de la libertad que es un principio incontrovertible, que aun en la duda debe decidirse a su favor...". ${ }^{70}$ Los Defensores de pobres no se cansaban de realzar la legitimidad que tenía la libertad como principio. El defensor Antonio José de Escalada aseveró que lo que estaba en juego era “...la cosa mas preciosa que puede tener el hombre, qual es la libertad". ${ }^{71}$ El defensor Pedro Gonzalez Cortinas se refirió a la situación de una parda y sus hijos esclavos como una "pasmosa tiranía". La venta de ellos había sido un "injusto e inhumano

65 AGN, Sala IX, Tribunales-Expedientes sin letra, 36-8-4, exp. 6, 1780. AHPBA, Juzgado del Crimen, 34-1-14-47, 1788. AHPBA, Criminal Provincial, 7.2.104.15, 1796. AHPBA, Criminalprovincial, 7.2.104.15, 1796.

${ }^{66}$ AGN, Sala IX, Tribunales-Expedientes sin letra, 36-8-4, exp. 12, 1785. El caso es relatado detalladamente en Levaggi, 1973: 98-102.

67 AGN, Sala IX, Administrativos, 23-4-7, Exp. 115, 1801. AGN, Sala IX, Administrativos, 23-4-7.

Exp. 167, 1801.

68 AGN, Sala IX, Interior, 30-6-9. Exp. 14, 1801.

${ }^{69}$ AGN, Sala IX, Administrativos, 23-4-6. Exp. 115, 1801.

70 AGN, Sala IX, Administrativos, 23-4-7. Exp. 167, 1801.

${ }^{71}$ AGN, Sala IX, Tribunales-Expedientes sin letra, 35-7-1, exp. 22, 1779. 
procedimiento" ya que "contra razón y derecho se han reducido al infeliz estado de esclavitud unos individuos que por su naturaleza tuvieron la felicidad de ser libres". ${ }^{72}$

En los casos de libertad por disposición testamentaria, los herederos solían argumentar que el valor de los esclavos manumitidos superaba el monto del cual podían disponer los difuntos -el quinto de los bienes-, afectando la legítima. Pero los defensores rebatían este aserto. Por ejemplo, Antonio José de Escalada argumentó que la regla de que no se podía disponer en un testamento de más de un quinto de los bienes conocía excepciones. La manumisión de un esclavo era una de ellas, porque la "piedad siempre que verdaderamente concurra es una dispensadora de la regla general". ${ }^{73}$ Algunos defensores sostuvieron que si los amos brindaban la libertad a sus esclavos era por los servicios que estos les habían brindado en vida. ${ }^{74}$ Otro defensor desacreditó a la esclavitud misma como contraria al "derecho natural [...] por tener su primer origen solo del cautiverio y la tiranía" mientras que "la libertad opuesta diametralmente a aquella [...] es conforme al derecho natural y a la piedad". ${ }^{75}$ El mayor alegato en contra de la esclavitud en boca de un Defensor de pobres lo encontramos en un escrito de Anselmo Saénz Valiente, quien aseveró que la esclavitud era:

“...una orrible y engañosa metamorfosis de la especie humana asi ha propendido la autoridad a favorecerla y desagraviarla con la posible restitución de sus derechos conforme ha sucedido la ilustración a la ignorancia, la suavidad de las costumbres a la primitiva ferocidad, y el conocimiento de los derechos del hombre se ha sustituido a la idea de preocupación de los antiguos y gentiles [...] La decadencia que ha sufrido de muchos siglos a esta parte el imperio de la ignorancia; el sacudimento que ha hecho la razón de las falsas ideas del antiguo derecho de gentes [...] hace conocer en el día que tan diversa idea es la que se tiene de la esclavitud en las naciones cultas. Algunas hay que no la conocen, otras que la han moderado excesivamente y otras en que se conserva por un temperamento político, necesario y conveniente para mayores beneficios de el hombre mismo."76

\footnotetext{
72 AHPBA, Civil provincial, 5.3.47.2, 1797.

73 AGN, Sala IX, Tribunales-Expedientes con letra, 40-8-2, exp. 1, 1780.

74 AGN, Sala IX, Tribunales-Expedientes con letra, 40-8-3, exp. 12, 1793. AGN, Sala IX, Administrativos, 23-4-7, 1801.

${ }^{75}$ AGN, Sala IX, Tribunales-Expedientes con letra, 42-8-5, exp. 15, 1778.

${ }^{76}$ AGN, Sala IX, Tribunales-Expedientes con letra, 40-8-3, exp. 12, 1793.
} 
Los Defensores de pobres impulsaron litigios para que se cumpliese el derecho a libertad por simple promesa del amo. ${ }^{77}$ La ley de partida que establecía como debía ser otorgada la libertad, aclaraba que podía ser mediante testamento, por carta o delante de sus amigos. Para que estas últimas dos formas tuviesen efecto debían realizarse ante cinco testigos. ${ }^{78}$ ¿Qué sucedía si el amo no otorgaba la libertad, sino que se comprometía a darla en el futuro a cambio de algo y luego no cumplía con su promesa? Las leyes guardaban silencio al respecto pero los esclavos y sus defensores creían que los amos debían cumplir con la promesa, porque en general los esclavos habían dado algo a cambio. ${ }^{79}$

Las causas en las que existían graves discrepancias entre esclavos -y sus defensores- y amos eran aquellas en las que las costumbres y parte de la jurisprudencia se contraponían a lo establecido por las leyes. Allí las discusiones no giraban en torno a los hechos, sino en contrapuestas interpretaciones jurídicas y doctrinales acerca de que derechos tenían preeminencia sobre otros. Esto sucedía cuando los esclavos pretendían comprar su libertad, cambiar de amo o elegir un comprador a su gusto en contra de la voluntad de sus amos. Aquí no parecía haber punto de acuerdo o un código compartido entre las partes, sino concepciones bastante opuestas sobre la relación amo-esclavo.

Cuando un esclavo buscaba comprar su propia libertad, un argumento frecuente de los amos es que no tenían derecho a poseer un peculio según las partidas, las cuales establecían que todos lo que ganasen los siervos le pertenecía a su señor, y que nadie podía ser forzado a vender lo que era suyo. ${ }^{80}$ Según ellos, solo se los podía obligar a vender a su esclavo o admitir el precio que estos ofrecían por su libertad, si existía maltrato, abandono, inducción a la prostitución o alguna de las otras causales previstas por la legislación. ${ }^{81}$ Un procurador de pobres -representando a un amo- fue claro al respecto: “...no ay ley, texto, ni doctrina alguna que obligue al amo a vender contra su propia voluntad el siervo [...] a excepción de tres casos, que son los de justificada

77 Casos de este tipo: AGN, Sala IX, Criminales, leg 2775, exp. 24, 1779. AGN, Sala IX, Tribunales-Expedientes sin letra, 35-9-3, exp. 51, 1781. AHPBA, Civil provincial, 5.4.60.10, 1794. AHPBA, Juzgado del crimen, 34-2-24-37, 1799.

${ }^{78}$ Las siete...., Tomo III, Partida IV, Título XXII, Ley I.

79 Esta seguramente es la razón por la cual casi todos los autores que han estudiado el ordenamiento legal esclavista hispanoamericano no incluyen en la lista de derechos de los esclavos el de la libertad por simple promesa del amo (Petit Muñoz, 1947; Lucena Salmoral, 2000; Gallego, 2005). Una excepción al respecto es Levaggi, 1973: 140-106.

80 AGN, Sala IX, Tribunales-Expedientes con letra, 41-3-3, exp. 15, 1796. AGN, Sala IX, Tribunales-Expedientes con letra, 41-1-1, exp. 13, 1797. AGN, Sala IX, Tribunales-Expedientes con letra, 42-4-6, exp. 1, 1787.

${ }^{81}$ AGN, Sala IX, Tribunales-Expedientes con letra, 40-4-6, exp. 13, 1798. 
sevicia, inducción al pecado o mudanza de religión...". ${ }^{82}$ Otro amo explicó que los esclavos: “...libres por naturaleza, pero reducidos a servidumbre por el dro de gentes (en cuio caso hablamos) no pueden obligar a su amo a que les de la libertad o los venda...". ${ }^{83}$ Para los amos, el esclavo era una cosa, y como cualquier otro bien mueble ellos podían decidir cuándo, cómo, dónde y a quién venderlo.

¿Qué podían alegar los Defensores de pobres frente a la contundencia de estos argumentos? El defensor Anselmo Saénz Valiente aseveró que "aunque sea cierto por regla gral de derecho que quanto adquiera el siervo es de su señor, esta regla se exceptua quando el amo da permiso a su esclavo para que adquiera para si alguna cosa" ${ }^{84}$ En un caso similar el defensor Francisco Neyra y Orellano aseveró que “...todo hombre tiene un privilegiado dro a restituirse y volver sin violencia al estado libre en que fue criado y puesto por el supremo autor [...] y ofrece incontinenti el justo precio...". ${ }^{85}$ Según el defensor Rodríguez de la Vega, la libertad era un principio acorde a los deseos de Dios y el monarca porque los esclavos no eran meros bienes muebles, sino "hermanos" que desafortunadamente se veían privados de un don natural. Como remedio de esta "suerte infausta" es que debía aceptarse la posibilidad de que se redimieran de la esclavitud entregando su precio a su amo. ${ }^{86}$ Había casos donde no estaba en juego la libertad de los esclavos. Pero estos buscaban elegir a quien servir. Para los amos era muy tentador vender a los esclavos en las "provincias de arriba" a un precio elevado. Pero los esclavos creían tener derecho a elegir comprador y acudían a la justicia para poder ser vendidos en la ciudad a un justo precio. ${ }^{87}$ Los defensores amparaban estos pedidos. Otra arma que tenían los defensores para usar en beneficio de sus asistidos en los casos que venimos relatando era la jurisprudencia. Existían antecedentes de esclavos que luego de largos litigios habían obtenido sentencia que obligaba a sus amos a aceptar en forma forzosa el dinero a cambio de manumitirlos. Algunas de estas demandas habían llegado hasta las más altas instancias de justicia, más precisamente al Consejo de Indias y al Rey. Los Defensores de pobres argumentaban que estas resoluciones del soberano sobre litigios puntuales tenían fuerza de ley y debían regir para casos semejantes. ${ }^{88}$

Los Defensores de pobres desde 1779 contaron también con una real orden del soberano que implícitamente iba en la misma dirección. Lo que había

\footnotetext{
${ }^{82}$ AGN, Sala IX, Tribunales-Expedientes sin letra, 36-5-1, exp. 5, 1786.

${ }^{83}$ AGN, Sala IX, Tribunales-Expedientes sin letra, 36-5-1, exp. 5, 1786.

${ }^{84}$ AGN, Sala IX, Tribunales-Expedientes con letra, 41-3-3, exp. 15, 1796.

${ }^{85}$ AHPBA, Criminal Provincial, 7.1.83.17, 1808.

${ }^{86}$ AGN, Sala IX, Tribunales-Expedientes sin letra, 36-1-1, exp. 12, 1777.

${ }^{87}$ AGN, Sala IX, Tribunales-Expedientes con letra, 42-4-6, exp. 1, 1787.

${ }^{88}$ AGN, Sala IX, Tribunales-Expedientes sin letra, 36-1-1, exp. 12, 1777. Algunos de de estos casos han sido descriptos en Levaggi, 1973: 126-134; 168-175.
} 
ocurrido era que un grupo de esclavos de Buenos Aires en carta a Carlos III, había clamado por "algún alivio a nuestra opresa servidumbre", sugiriendo que tal paliativo podía consistir en que se les otorgase la libertad cumplidos diez años de servicio. Sin acceder completamente a tal pedido, el soberano en carta al Virrey, había señalado la necesidad de que "estos miserables gozen de algún beneficio compatible con su esclavitud" (Levaggi, 1973: 128-129). Rodríguez de la Vega por ejemplo interpretaba este deseo del soberano como la constatación de que la esclavitud era "un odio a la humanidad, y el mas enorme de los agravios que se han hecho a la naturaleza, y que por esto, quando por razón de estado no pueda suprimirse, a lo menos piensa en dulcificarla..." 89 Los defensores no solo les recordaban a los magistrados que los esclavos eran personas, sino que además eran miserables merecedores de amparo y piedad por parte las autoridades. Esta retórica ponía en aprietos a los amos. Juan Díaz, el amo del negro Antonio se quejó de esta estrategia de los defensores al decir: "ha sido muy del caso también, pretender excitar la compasión de esta superioridad a favor del negro Antonio, llamándolo miserable". ${ }^{90}$

En los escritos que los amos dirigían a los magistrados dejaban entrever que lo que estaba en juego no era solo la relación personal que ellos podían tener con el esclavo que los había demandado, sino los pilares de una institución vital para la sociedad. En su visión, una sola sentencia favorable a los esclavos podía resquebrajar las bases sobre las que reposaban la obediencia y sumisión de todos los siervos de la ciudad hacia sus dueños, con alteración del orden público. ${ }^{91}$ Si bien dicho temor de "clase" podía resultar exagerado y no dejaba de ser una estrategia más de los amos para obtener una resolución favorable en los estrados, el hecho de que se aludiera tantas veces a este tema nos habla a las claras que era un argumento creíble. Si los jueces prestaban sus oídos a los esclavos no solo impulsaban a muchos más a acudir a la justicia, sino que resentían considerablemente la sumisión que los demás esclavos debían exhibir frente a sus amos, volviéndolos altaneros. Un amo se quejó al decir que "con motivo de las gestiones que han hecho mis esclavos, no tengo uno que me guarde el respeto debido que me obedezca ni me esté sugeto como es propio y corresponde a todo esclavo respecto de sus amos" ${ }^{92}$

Por estas razones a los amos les incomodaba que los esclavos cuando los demandaban ante la justicia tuviesen la asistencia del Defensor de pobres. José

\footnotetext{
${ }^{89}$ AGN, Sala IX, Tribunales-Expedientes sin letra, 36-1-1, exp. 12, 1777.

90 AGN, Sala IX, Administrativos, 23-07-07, exp. 846, 1809. Un caso similar AGN, Sala IX, Tribunales-Expedientes con letra, 41-3-3, exp. 15, 1796.

${ }^{91}$ Los testimonios al respecto son múltiples. AGN, Sala IX, Tribunales-Expedientes sin letra, 368-4, exp. 6, 1780. AGN, Sala IX, Tribunales-Expedientes sin letra, 36-5-1, exp. 5, 1786. AGN, Sala IX, Hacienda, Leg. 52, exp. 1351, 1788. AHPBA, Civil Provincial, 5.4.60.10, 1794. AGN, Sala IX, Tribunales-Expedientes con letra, 41-3-3, exp. 15, 1796.

${ }_{92}$ AGN, Sala IX, Tribunales-Expedientes con letra, 40-4-6, exp. 13, 1798.
} 
Perfecto Salas bramó en contra del defensor cuando este con sus gestiones impidió momentáneamente que pudiese vender a su esclavo en otra provincia y dijo que se había excedido "de las verdaderas obligaciones de su cargo". ${ }^{93}$ Doña Josefa García de Orcajo también se quejó amargamente de la actuación del Defensor de pobres a favor del demandante. Aseveró que su esclavo "andando a su alvedrio habrá contraído muchos vicios, que yo habre de pagar nada mas que por la tenacidad de sus defensores y su irregular patrocinio". ${ }^{94}$ Otro amo se quejaba de que ante cualquier corrección doméstica los esclavos acudían a los juzgados a quejarse por tener "...varios exemplares de haverse protegido algunos por los defensores de pobres y alcanzado sus pretensiones...". ${ }^{95}$ Algunos amos iban aún más lejos, y acusaban a los defensores de esconder a los esclavos. Clara Echenique, al informar que la demandante se había fugado de su casa alimentó esta sospecha al decir "rezelo que esta en casa del Defensor de pobres Don Martín de Álzaga". ${ }^{96}$ Otro amo adujo que los esclavos lo único que buscaban era vivir "sin ley y sin señor" y que no les faltaban "defensores que patrocinen sus intentos". 97

\section{Fallos de los jueces y consecuencias sociales de las querellas}

¿Qué éxito tenían los esclavos asistidos por los Defensores de pobres? En los casos de litigios por malos tratos lo que puede advertirse es que la resolución que predominaba en los jueces era una especie de solución negociada, en la cual se trataba de acercar posiciones. En un solo caso se le dio la razón al amo, y solo en otro se accedió a todo lo que pedía el esclavo. El resto de las sentencias buscaban un equilibrio entre el derecho al buen trato de los esclavos y el derecho de propiedad de los amos. ${ }^{98}$ En ocasiones, los jueces a pesar de no otorgar el papel de venta reprendían a los amos por sus "excesos" y los amenazaban con futuras sanciones si la situación persistía. Algunos autores han interpretado estos retos y exhortaciones a los amos de esclavos como una prueba de que "la administración de justicia estuvo efectivamente al servicio de la integridad física de los esclavos" (Levaggi, 1973: 113). Si bien para adherir o rechazar esta conclusión deberíamos analizar la totalidad de expedientes en los cuales los esclavos demandaban a sus amos -y no solo en los que tuvieron intervención los Defensores de pobres-, lo cierto es que el análisis de nuestra muestra nos permite al menos matizar dicha afirmación. Los magistrados solo

\footnotetext{
${ }^{93}$ AGN, Sala IX, Tribunales-Expedientes sin letra, 38-5-4, exp. 3, 1778.

${ }^{94}$ AGN, Sala IX, Tribunales-Expedientes sin letra, 35-7-1, exp. 22, 1779.

${ }^{95}$ AGN, Sala IX, Tribunales-Expedientes sin letra, 36-8-4, exp. 6, 1780.

${ }^{96}$ AGN, Sala IX, Tribunales-Expedientes sin letra, 36-8-4, exp. 12, 1785.

${ }^{97}$ AGN, Sala IX, Tribunales-Expedientes con letra, 42-4-6, exp. 1, 1787.

${ }_{98}$ AGN, Sala IX, Tribunales-Expedientes sin letra, 36-8-4, exp. 6, 1780. AHPBA, Juzgado del crimen, 34-1-14-47, 1788. AHPBA, Criminal-provincial, 7.2.104.15, 1796. AGN, Sala IX, Tribunales-Expedientes con letra, 41-8-3, exp. 13, 1798.
} 
excepcionalmente accedían totalmente a las solicitudes de los esclavos. La sanción a los amos por maltratar a sus esclavos según las leyes de por sí era leve, y se limitaba a ordenar la venta por justo precio del demandante. Aun así, pocas veces los jueces obligaban a los denunciados a vender a sus siervos. Los amos parecían tener el derecho a una segunda oportunidad.

En las demandas de libertad por haber sido esclavizados injustamente, los esclavos parecían concitar más piedad en los jueces. De hecho, en más de la mitad de las demandas de este tipo, las sentencias dieron la razón a los esclavos, otorgándoles la libertad. En las cuatro restantes tampoco se falló a favor de los pretendidos amos, sino que se adoptaron soluciones intermedias. ${ }^{99}$ También solían ser exitosos los esclavos que reclamaban su libertad por disposición testamentaria de su amo. En dos oportunidades se concedió la libertad a los esclavos querellantes, en otro se llegó a una solución intermedia y en un caso se rechazó la solicitud. A medida que el número de causas va descendiendo, sacar algún tipo de conclusión general en torno a las resoluciones de los casos se torna más aventurado por lo reducido de la muestra. En las causas de solicitudes de libertad por promesa del amo también predominaban las sentencias favorables a los esclavos, aunque estaban presentes todas las soluciones posibles. ${ }^{100}$ En su conjunto, las demandas por motivos muy infrecuentes también se resolvían en general a favor de los esclavos. ${ }^{101}$

Al momento de repasar los litigios en los que los esclavos buscaban cambiar de amo o comprar su propia libertad contra la voluntad de sus amos, vimos que algunas causas renombradas habían terminado con sentencias favorables a los demandantes. Pero esta no era la situación más frecuente. De los ocho casos de este tipo analizados, solo uno se resolvió a favor del esclavo. Tres están inconclusos, en otros tres se falló en contra del demandante y en uno se arribó a una solución negociada. En una sentencia el juez explicitó que los casos jurisprudenciales citados por los defensores en favor de los esclavos eran "concesiones o gracias particulares [...] comprendidos en la excepción de la regla". Estos actos piadosos del soberano de ninguna manera debían ser una norma general aplicable a todos los casos. ${ }^{102}$ Si existía una tendencia a fines del siglo XVIII que se caracterizaba por reconocer a los esclavos el derecho a

99 AGN, Sala IX, Tribunales-Expedientes sin letra, 35-7-1, exp. 22, 1779. AGN, Administrativos, 23-4-6, exp. 115.

100 AHPBA, Juzgado del Crimen, 34-2-24-37, 1799. AHPBA, Civil provincial, 5.4.60.10, 1794.

101 Por ejemplo, las dos causas referidas al derecho al peculio finalizaron con sentencias favorables al demandante. AGN, Sala IX, Tribunales-Expedientes con letra, 41-3-3, exp. 15, 1796. El esclavo que ansiaba casarse pudo conseguir el permiso el permiso de su amo. AGN, Sala IX, Tribunales-Expedientes con letra, 42-1-7, exp. 10, 1788. Y el apoderado del amo de otro esclavo fue reprendido por el castigo excesivo que quería propinarle. AHPBA, Criminal provincial, 5.5.76.2, 1807.

102 AGN, Sala IX, Hacienda, leg 52, exp. 1351, 1788. 
cambiar de amo o comprar su libertad con independencia de la voluntad de su amo -como algunos autores han sugerido-, en nuestra muestra esta preferencia no era dominante.

En resumen, el recuento total de todas las sentencias de nuestra muestra de litigios arroja que aquellas favorables al esclavo conformaban la primera minoría $-39 \%-$. Le seguían muy de cerca los litigios en los que se arribaba a alguna solución negociada, es decir que no se accedía completamente al pedido del querellante pero tampoco se le daba la razón al amo -34\%-. En tercer lugar, lejos, se ubicaban las sentencias adversas al esclavo $-17 \%-$. Por último, un pequeño número de causas $-10 \%$ - aparecen inconclusas, sin que tengamos forma de saber cuál fue la resolución final, o si el proceso se detuvo por algún arreglo extrajudicial. Estos datos nos indican que las chances de obtener algún beneficio acudiendo a la administración de justicia eran significativas para los esclavos. ¿Tenían mejores resultados en los juzgados los esclavos asistidos por los defensores que los que no contaban con el patrocinio de este regidor? Para responder a este interrogante, deberíamos ampliar la muestra incluyendo todos los litigios que involucraban a los esclavos como demandantes. Dicha tarea queda pendiente para futuras investigaciones. ${ }^{103}$

\section{Consideraciones finales}

La evidencia aportada permite afirmar -como otros estudios ya lo habían señalado- que en el Buenos Aires tardocolonial al menos un conjunto de esclavos logró efectivizar uno de los derechos que la legislación les otorgaba, el de la asistencia judicial. Ello implicaba poder presentarse a la justicia y contar con el patrocinio jurídico gratuito del Defensor de pobres. Lo primero estaba expresamente regulado en las leyes, no así lo segundo. No obstante, era reconocido como un derecho de los esclavos. En el presente trabajo no nos conformamos con constatar esta realidad, sino que intentamos mostrar las características asumidas por esta representación jurídica en toda su complejidad. Así como en algunos casos el patrocinio se iniciaba producto de

\footnotetext{
${ }^{103}$ Lyman Johnson, quien ha considerado este corpus documental en toda su amplitud, ha afirmado que la mayoría de los esclavos generalmente obtenían sentencias desfavorables. Si nos guiamos por esta afirmación, la intervención de los Defensores de pobres acrecentaba las posibilidades de los esclavos de alcanzar "su justicia" (Johnson, 2007). De todas maneras, como ha señalado el mismo autor entablar un litigio podía llegar a implicar beneficios para los esclavos más allá de la sentencia. Desprestigiaban a su amo dando a conocer los maltratos que sufrían al hacerlos públicos en una demanda, con notable perjuicio para su honor. Durante el tiempo que duraba el pleito muchas veces huían, se sustraían a su dominio y dejaban de rendirle los jornales. Además, obligaban al amo a incurrir en los gastos del litigio (costas, abogado, papel sellado) mientras ellos estaban exentos de dichas erogaciones por ser miserables. A veces una demanda que duraba años desgastaba tanto la relación que al final el amo optaba por desprenderse de su esclavo. O en adelante se cuidaba de no maltratarlo en exceso.
} 
una imposición del juez, en otro era una solicitud de los mismos esclavos. Existían Defensores de pobres muy comprometidos con su labor. Pero otros parecían ejercer el oficio a desgano. La variabilidad que exhibían los Defensores de pobres en el desempeño de su labor era notable. Mientras algunos eran denunciados por cómplices de los amos por los esclavos, otros parecían congraciarse con los reclamos de sus asistidos. En un litigio, por equivocación el Virrey determinó que el Defensor de pobres interviniese, pero en representación del amo denunciado. Ante esta situación el defensor aclaró que la disposición debía estar equivocada, ya que no constaba la pobreza del amo demandado "debiéndose suponer la del esclavo". De todas formas se encargó de aclarar que en caso de no ser errónea la medida, desistía de defender al amo ya que “...tiene mostrada su opinión que en su conciencia es que se debe dar libertad al esclavo que ofrece su justo precio, siempre que justifique no haverlo usurpado a su amo". ${ }^{104}$ Rodríguez de la Vega estaba interponiendo una verdadera objeción de conciencia al negarse a defender al amo.

Durante el tiempo que duraba el patrocinio brindado por los Defensores de pobres, la relación entre estos regidores y sus asistidos no estaba exenta de desacuerdos. Por ello, la asistencia desempeñada por estos defensores era solo una de las tantas formas de acceso a la justicia que practicaban los esclavos, no la única. También se presentaban a la justicia por su cuenta, o acudían a la ayuda de familiares, terceros o abogados. Incluso a lo largo de un litigio podían cambiar de representante, según la estrategia judicial que juzgaran más conveniente. La Real Cédula... de 1789 tuvo escaso impacto en las demandas patrocinadas por los defensores. En caso de haber entrado en vigor inmediatamente la responsabilidad del patrocinio a los esclavos debería haber sido traspasado al Síndico Procurador, cosa que no ocurrió. Pero además dicha normativa no era utilizada en sus argumentaciones. En contrapartida las partidas eran mencionadas con frecuencia.

Pero los Defensores de pobres en el desempeño de su labor no solo se restringían a citar las leyes favorables a los esclavos, sino que invocaban preceptos y principios antiguos que gozaban de legitimidad, como el derecho natural, la piedad, la equidad, los deseos de Dios y el Rey, la humanidad o la justicia. ${ }^{105}$ Algunos defensores hacia el final del período añadieron otros valores -como la ilustración, los derechos del hombre y la razón-, y mencionaron el cuestionamiento que la institución estaba sufriendo en algunas partes del mundo. Ninguno de estos órdenes normativos determinaba de antemano el resultado que podía llegar a tener una demanda entablada por un esclavo contra su amo. Era el uso que los actores hacían de estas múltiples fuentes del

104 AGN, Sala IX, Criminales, Leg. 2775, exp. 24, 1779-1780.

105 Petit Muñoz al tratar de identificar las corrientes que favorecían los derechos de los esclavos, mencionó entre ellas la piedad del soberano, o la apelación a ciertos valores generales como la caridad o la humanidad (Petit Muñoz, 1947: 555). 
derecho en circunstancias específicas lo que influía en la resolución de estas demandas. Manuela Zabaleta, negra esclava, afirmó que el favor de su libertad estaba amparado por "la piedad del soberano, el derecho de gentes y la práctica inconcusa de esta ciudad". ${ }^{106}$

La libertad se condecía con múltiples órdenes normativos, pero razones de orden público impedían declarar la abolición de la esclavitud según los defensores. Por lo tanto, quedaba el camino de aminorarla reprimiendo los abusos, y admitir el derecho a la libertad de aquellos esclavos que por alguna causa fueran merecedores de este privilegio. ${ }^{107}$ Así se ampliaban considerablemente los derechos reservados a estos miserables, haciendo menos penosa su situación. Sin embargo, pese a no ser abolicionistas, los Defensores de pobres llegaron a cuestionar con serios argumentos los fundamentos sobre los cuales reposaba esta institución. Un defensor explicó que según las partidas la esclavitud provenía de una actitud humanitaria de los hombres en el pasado, quienes para no ejecutar a los prisioneros de guerra habían decidido esclavizarlos. Luego agregó que era obvio que los esclavos actuales no eran guerreros cautivos sino africanos capturados y comprados por dinero, "infelices que no han hecho la menor ofensa". ${ }^{108}$

No eran solo argumentos radicales como el expuesto lo que molestaba a los amos. Si los esclavos acudían a los tribunales, eran asistidos gratuitamente por los Defensores de pobres, y además obtenían sentencias favorables, la situación podía volverse insostenible. Los esclavos adquirían conciencia de sus derechos y adoptaban hábitos que socavaban el dominio de los amos. ¿Cómo se anoticiaban de las sentencias favorables que obtenían sujetos de su misma condición cuando acudían a la justicia? La libertad de movimientos de la que gozaban seguramente favorecía la circulación de información en calles, plazas, pulperías y otros ámbitos de sociabilidad popular. Un testimonio de un amo es sugerente al respecto. Al momento de producir prueba, elaboró una pregunta para que los testigos respondieran si era cierto que su esclavo lo había demandado por los consejos de "su madre, un mulato Juan Antonio esclavo de Don Francisco de Escalada y una criada de Don Martin de Álzaga". ${ }^{109}$ A juzgar por estos dichos, la labor que ejercían los defensores llegaba a oídos de los esclavos que servían en sus casas y estos transmitían estas novedades a otras personas de su misma condición. Así los esclavos se familiarizaban con ciertos

\footnotetext{
106 AGN, Sala IX, Tribunales-Expedientes sin letra, 36-5-1, exp. 5, 1786.

107 En este punto coincidimos con Lyman Johnson, quien aseveró: “...some of the powerful Spaniards and creoles who served as defensores - men who owned slaves and benefited from their labor- recognized that the institution permitted widespread abuse, understood that the power of masters served as an invitation to cruelty, and then acted to mitigate these injustices." (Johnson, 2007: 657).

108 AGN, Sala IX, Hacienda, leg. 52, exp. 1351.

109 AHPBA, Criminal Provincial, 7.2.104.15, 1796.
} 
saberes judiciales. Las diatribas que los dueños de esclavos profirieron cuando fueron obligados a dar explicaciones ante las autoridades algo nos dicen. El patrocinio jurídico gratuito ejercido por los Defensores de pobres podía tener sus limitaciones. Pero es claro que los amos hubieran preferido que no existiera esta asistencia judicial que se brindaba a quienes gemían bajo el "pesado yugo de la esclavitud". ${ }^{110}$

\section{Bibliografía citada}

Agüero, Alejandro (2005). “Saber jurídico y técnica procesal en la justicia lega de la periferia. Reflexiones a partir de documentos judiciales de Córdoba del Tucumán, siglos XVII y XVIII", en Torres Aguilar, Manuel (Coord.) Actas del XV Congreso del Instituto Internacional de Historia del Derecho Indiano, Córdoba (España), t. I, pp. 311-332.

Agüero, Alejandro (2006). "Las categorías básicas de la cultura jurisdiccional", en Lorente Sariñena, Marta De justicia de jueces a justicia de leyes: hacia la España de 1870, Madrid: Consejo General del poder judicial - Centro de documentación judicial, pp. 19-58.

Aguirre, Carlos (1995). Agentes de su propia libertad. Los esclavos de Lima y la desintegración de la esclavitud 1821-1854, Lima: Pontificia Universidad Católica del Perú.

Andrews, George Reid (1989). Los afroargentinos de Buenos Aires, Buenos Aires: Ediciones de la Flor.

Azevedo, Elciene (2007). "En las trincheras de la historia. Abogados y esclavos en el movimiento abolicionista de San Pablo", en Palacio, Juan Manuel y Candioti, Magdalena (comps.) Justicia, política y derechos en América Latina, Buenos Aires: Prometeo, pp. 107-126.

Barriera, Darío y Polimene María Paula (2010). "Justicias y sociedades. Bocacalles trazadas desde la historia", en Barriera, Darío La justicia y las formas de la autoridad. Organización politica y justicias locales en territorios de frontera. El Río de la Plata, Córdoba, Cuyo y Tucumán, siglos XVIII y XIX, Rosario: ISHIR CONICET-Red Columnaria, pp. 9-16.

Bernand, Carmen (2000). “La población negra de Buenos Aires (1777-1862)”, en Quijada, Mónica; Bernand, Carmen y Schneider, Arnd Homogeneidad y nación, con un estudio de caso: Argentina, siglos XIX y XX, Madrid: Consejo Superior de Investigaciones Científicas.

Bernand, Carmen (2001). Negros esclavos y libres en las ciudades hispanoamericanas, Madrid: Fundación Histórica Tavera.

110 Esta expresión fue utilizada por un esclavo para referirse a su situación. AGN, Sala IX, Tribunales-Expedientes sin letra, 36-1-1, exp. 12, 1777. 
Borah, Woodrow (1985). El juzgado general de indios en la Nueva España, México: Fondo de Cultura Económica.

Borucki, Alex (2011). "The slave trade to the Río de la Plata, 1777-1812: Transimperial Networks and Atlantic Warfare", en Colonial Latin American Review, vol. 20, núm 1, pp. 81-107.

Borucky, Alex (2017). De compañeros de barco a camaradas de armas. Identidades negras en el Río de la Plata, 1760-1860, Buenos Aires: Prometeo.

Candioti, Magdalena (2010). “Altaneros y libertinos. Transformaciones de la condición jurídica de los afroporteños en la Buenos Aires revolucionaria (18101820)", en Desarrollo Económico, Buenos Aires, vol. 50, núm. 198, pp. 271-296.

Casals, Laura (2011). “Africanos y afrodescendientes en el Buenos Aires tardocolonial: Una mirada sobre el cuerpo", en Boletín Americanista, Barcelona, año LXI 2, núm. 63, pp. 35-56.

Comadrán Ruiz, Jorge (1969). Evolución Demográfica Argentina Durante el Período Hispano (1535-1810), Buenos Aires: Eudeba.

Crespi, Liliana (2007). Vidas de esclavos. Las complejidades jurídicas a la hora de reclamar derechos. Aspectos de la aplicación de la ley en el Río de la Plata durante el período indiano, Luján: Tesis de maestría en Ciencias Sociales con Mención en Historia Social, Universidad Nacional de Luján, inédita.

Crespi, Liliana "Ni esclavo ni libre. El status del liberto en el Río de la Plata desde el período indiano al republicano", en Mallo, Silvia; Telesca, Ignacio (eds.) Negros de la patria. Los afrodescendientes en las luchas por la independencia en el antiguo Virreinato del Río de la Plata, Buenos Aires: SB, pp.15-38.

Cunill, Caroline (2012). Los defensores de indios de Yucatán y el acceso de los mayas a la justicia colonial, 1540-1600, Mérida: Centro Peninsular en Humanidades y Ciencias Sociales-Universidad Nacional Autónoma de México.

Cutter, Charles (1986). The Protector de Indios in colonial New Mexico, 1659-1821, Alburquerque: University of New Mexico Press.

De la Fuente, Alejandro (2004). "La esclavitud, la ley y la reclamación de derechos en Cuba: repensando el debate Tannembaum", en Debate y Perspectivas: Cuadernos de Historia y Ciencias Sociales, Madrid, núm. 4, pp. 37-69.

De la Fuente, Alejandro (2007). "Slaves and the creation of legal rights in Cuba: coartación and papel", en Hispanic American Historical Review, vol. 87, núm 4, pp. 659-692.

Díaz, Aisnara Perera y Meriño Fuentes, María de los Ángeles (2015). Estrategias de Libertad. Un acercamiento a las acciones legales de los esclavos en Cuba (1762-1872), Tomos I y II, La Habana: Editorial de Ciencias Sociales.

Finley, Moses (1982). Esclavitud antigua e ideología moderna, Barcelona: Crítica. 
Gallego, José Andrés (2005). “La esclavitud en la monarquía hispánica: Un estudio comparativo", en Gallego, José Andrés (dir.) Tres grandes cuestiones de la historia de Iberoamérica: ensayos y monografías: Derecho y Justicia en la historia de Iberoamérica: Afroamérica, la tercera raíz: Impacto en América de la expulsión de los jesuitas (CD-Rom con 51 monografías), Madrid: Fundación Histórica Tavera.

García Gallo, Concepción (1980). "Sobre el ordenamiento jurídico de la esclavitud en las indias españolas", en Anuario de Historia del Derecho Español, Tomo I, Madrid.

Goldberg, Marta (1976). “La población negra y mulata de la ciudad de Buenos Aires, 1810-1840", en Desarrollo Económico, vol. 16, núm. 21, pp. 75-99.

Goldberg, Marta (2005). “Introducción”, en Goldberg, Marta (dir.) Vida cotidiana de los negros en Hispanoamérica, Madrid: Fundación Ignacio LarramendiFundación MAPFRE Tavera, pp. 1-39.

González Undurraga, Carolina (2012). “El abogado y el procurador de pobres: la representación de esclavos y esclavas a fines de la Colonia y principios de la República", en Sudhistoria, núm. 5, pp. 81-98.

González Undurraga, Carolina (2014). Esclavos y esclavas demandando justicia, 1740-1823. Documentación judicial por carta de libertad y papel de venta, Santiago de Chile: Editorial Universitaria.

Johnson, Lyman (1979). “Manumission in colonial Buenos Aires, 1776-1810”, en Hispanic American Historical Review, vol. 59, núm. 2, pp. 258-279.

Johnson, Lyman (2007). "A lack of legitimate Obedience and Respect: Slaves and their Masters in the Courts of Late Colonial Buenos Aires", en Hispanic American Historical Review, núm. 87:4, pp. 631-657.

Johnson, Lyman y Socolow, Susan (1980). "Población y espacio en el Buenos Aires del siglo XVIII", en Desarrollo Económico, núm. 20: 79, pp. 329-349.

Klein, Herbert (1967). Slavery in the Americas. A comparative study of Virginia and Cuba, Chicago: University of Chicago Press.

Klein, Herbert (1986). La esclavitud africana en América Latina y el Caribe, Madrid: Alianza.

Kluger, Viviana (2003). “¿Todo tiempo pasado fue mejor? La condición jurídica del esclavo a través de la mirada de los fiscales de la Audiencia de Buenos Aires (1785-1812)", en Revista jurídica Universidad Interamericana de Puerto Rico, núm. 38.1, pp. 1-19.

Levaggi, Abelardo (1973). “La condición jurídica del esclavo en la época hispánica", en Revista de Historia del Derecho, Buenos Aires, núm. 1, pp. 83-175. 
Lucena Salmoral, Manuel (1995). “La esclavitud americana y las partidas de Alfonso $X^{\prime \prime}$, en Indagación: revista de historia y arte, núm. 1 (Ejemplar dedicado a: las minorías sociales y su expresión en el tiempo), pp. 33-44.

Lucena Salmoral, Manuel (1999). “El derecho de coartación del esclavo en la América Española", en Revista de Indias, núm. 216, vol. LIX, pp. 357-374.

Lucena Salmoral, Manuel (2000). “Leyes para esclavos. El ordenamiento jurídico sobre la condición, tratamiento, defensa y represión de los esclavos en las colonias de la América Española", en Gallego, José Andrés (dir.) Tres grandes cuestiones de la historia de Iberoamérica: ensayos y monografías: Derecho y Justicia en la historia de Iberoamérica: Afroamérica, la tercera raíz: Impacto en América de la expulsión de los jesuitas (CD-Rom con 51 monografías), Madrid: Fundación Histórica Tavera.

Mallo, Silvia (1991). "La libertad en el discurso del estado, de amos y esclavos. 1780-1830", en Revista de Historia de América, núm. 112, pp. 121-146.

Mallo, Silvia (2005). "Espacio Atlántico y esclavitud en el Virreinato del Río de la Plata: Experiencias de vida, formas de trabajo y búsqueda de libertad", en $L a$ Ruta del Esclavo en el Río de la Plata: su historia y sus consecuencias, Montevideo: UNESCO-MERCOSUR, pp. 55-74.

Mayo, Carlos (2004). Estancia y Sociedad en la pampa (1740-1820), Buenos Aires: Biblos.

Morgan, Edmund (2009). Esclavitud y libertad en los Estados Unidos, de la colonia a la independencia, Buenos Aires: Siglo XXI.

Obando Andrade, Rafael Ángel (2011). “Manumisión, coartación y carta de venta: tres de los mecanismos legales de obtención de la libertad para los esclavos negros en la América Española", en Revista de Historia de América, núm. 145, pp. 103-125.

Owensby, Brian (2005). "How Juan and Leonor Won Their Freedom: Litigation and Liberty in Seventeenth-Century Mexico", en Hispanic American Historical Review, núm. 85/1, pp. 39-80.

Owensby, Brian, (2011). "Pacto entre rey lejano y súbditos indígenas. Justicia, legalidad y política en Nueva España, siglo XVIII", en Historia Mexicana, Vol. 61, núm.1, pp. 59-106.

Palacio, Juan Manuel (2005-2006). “Hurgando en las bambalinas de la 'paz del trigo': algunos problemas teórico-metodológicos que plantea la historia judicial", en Quinto Sol, núm. 9-10, pp. 99-123.

Perri, Gladys (2009). “Los esclavos frente a la justicia. Resistencia y adaptación en Buenos Aires, 1780-1830", en Fradkin, Raúl Osvaldo La ley es tela de araña. Ley, justicia y sociedad rural en Buenos Aires, 1780-1830, Buenos Aires: Prometeo, pp. 51-82. 
Petit Muñoz, Eugenio (1947). “La condición jurídica”, en Petit Muñoz, Eugenio; Narancio, Edmundo y Traibel Nelcis, José La condición jurídica, social, económica y política de los negros durante el coloniaje en la Banda Oriental, Montevideo: Publicaciones oficiales de la Facultad de Derecho y Ciencias Sociales, pp. 57583.

Pugliese Lavalle, María Rosa (1996). “Los defensores de pobres y menores en el período indiano", en Congreso Internacional. 500 años de Hispanidad, 1492-1992, T. II, Mendoza, Universidad Nacional de Cuyo, Facultad de Filosofía y Letras, pp. 477-499.

Pugliese, María Rosa (2000). De la justicia lega a la justicia letrada, Buenos Aires: Junta de estudios históricos de San José de Flores.

Rebagliati, Lucas (2014). “¿Una esclavitud benigna? La historiografía sobre la naturaleza de la esclavitud rioplatense", en Andes, vol. 25, núm. 2.

Rebagliati, Lucas (2016). Pobreza, Caridad y Justicia en Buenos Aires: los defensores de pobres (1776-1821), Buenos Aires: Tesis de doctorado en Historia, Facultad de Filosofía y Letras de la Universidad de Buenos Aires, inédita.

Saguier, Eduardo (1989). "La naturaleza estipendiaria de la esclavitud urbana colonial. El caso de Buenos Aires en el siglo XVIII", en Revista Paraguaya de Sociología, año 26, núm. 74, pp. 45-54.

Schlez, Mariano “¿Esclavistas versus monopolistas? Las disputas en torno al tráfico de esclavos en el Virreinato rioplatense (1780-1810)", en Boletín Americanista, Barcelona, año LXVI. 1, núm. 72, pp. 133-154.

Scott, Rebecca (1989). La emancipación de los esclavos en Cuba: La transición al trabajo libre, 1860-1899, México: Fondo de cultura económica.

Secreto, María Verónica (2010). “Justica Na Desigualdade: açoes de liberdade, 'papéis de venda' e 'justo preço', rio da prata, 1776-1815”, en Afro-Ásia, núm. 42, pp. 27-62.

Socolow, Susan (1991). Los mercaderes del Buenos Aires virreinal: familia y comercio, Buenos Aires: Ediciones de la Flor.

Stern, Steve (1986). Los pueblos indígenas del Perú y el desafío de la conquista española, Madrid: Alianza.

Tannembaum, Frank (1972). El negro en las Américas. Esclavo y ciudadano, Buenos Aires: Paidós.

Tau Anzoátegui, Víctor (2001). El poder de la costumbre. Estudios sobre del derecho consuetudinario en América hispana hasta la emancipación, Buenos Aires: Instituto de Investigaciones de Historia del Derecho. 
Torre Revello, José (1961). “Origen y aplicación del código negrero en la América española", en Boletín del Instituto de Investigaciones Históricas, Buenos Aires, núm. XV, pp. 42-50.

Wasserman, Fabio (2011). Juan José Castelli. De súbdito de la corona a líder revolucionario, Buenos Aires: Edhasa.

Zapata de Barry, Ana María (2007). “El protector de Naturales y el Defensor General de Pobres en la estructura jurídica colonial de la América Hispana", en Ministerio Público de la Defensa, año 1, núm. 3, pp. 119-123.

Zapata de Barry, Ana María (2013). El defensor de pobres como defensor de esclavos (1722 a 1839), Bahía Blanca: Editorial de la Universidad Nacional del Sur.

Zorraquín Becú, Ricardo (1952). La organización judicial argentina en el período hispánico, Buenos Aires: Librería del Plata. 